\title{
A Few Words About Artists' Books
}

Steven Clay

Artists' books have finally come of age. The explosion of activity by artists exploring the realms of "the book" is maturing and gathering an identity uniquely its own. The confluence of traditions, concerns, aesthetics, media, structures, strategies, politics and content has given rise to an awareness of an international network of artists for whom the book is the primary form of expression. The works produced by these artists do not often neatly fit into any previously established tradition of art or bookmaking; in fact they are often characterized by their very defiance of categorization. Books take forms ranging from cheaply made photocopied or offset works to lavish one-of-a-kind or small edition handmade books, from sculptural and installation objects to electronic and hypermedia works, from books which are primarily text based to those which are purely visual, and everything in between. The influences are many and each individual book might evoke its own particular set of references. Certainly the traditions of independent literary publishing and the limited edition come into play but the present work under consideration must be more properly contextualized within the sensibility of postWorld War II cross disciplinary activity within the arts.

Artists such as John Cage, Merce Cunningham, Stan Brakhage, Carolee Schneemann, Yvonne Rainer; "movements" or "schools" such as Fluxus, the Beats, and Black Mountain College enacted an energy of innovation and serve as possible intellectual and aesthetic mentors. Dick Higgins, in his important essay of 1965 "Intermedia" sheds light on the concept of 
works of art which "fall between media." 1 It is within the context of this explosion of experimental art and publishing activity and the blurring or combining of genres that the works at hand might be better understood.

Granary Books, now located in New York City, was established in 1982 as a distributor for "fine press" literary books but over the intervening years has evolved into a gallery and publisher for contemporary artists' books. In the gallery, during the past five years, works from over 200 artists have been exhibited. These shows give testimony to the range, depth and shifts in current bookmaking. Additionally, Granary has published ten artist book editions in the past three years.

David Schoonover, Curator of Rare Books, University of Iowa Libraries, has been watching and charting this shift in the book world at least since we first met in 1987. Although initially we worked together to enhance and expand the Library's excellent collection of fine press books, Mr. Schoonover early on began to acquire examples of work which fell somewhat outside the domain of this established tradition. Several of the publications of Granary housed in the Special Collections Department, all produced in 1992, will serve well as examples.

Synesthesia is by Timothy C. Ely and Terence McKenna. Timothy Ely is a well-known book artist whose imaginative and enigmatic vision has found its presence in the form of one-ofa-kind hand drawn, painted and bound books for about fifteen years. His hieroglyphic and cartographic mappings of unknown and alien spaces and languages are curiously synchronized with the writings of West Coast philosopher and ethnobotanist Terence McKenna. Mr. McKenna has for thirty years been exploring the realms of human perception and consciousness; his recent book publications include The Archaic Revival and Food of the Gods. The overlapping concerns between these two individuals were obvious and the notion of a collaboration quickly became ripe. McKenna's text addresses the broad range

${ }^{1}$ Dick Higgins, "Intermedia," in Young American Writers, ed. by Richard Kostelanetz (New York: Funk \& Wagnalls, 1967), 191-196. 


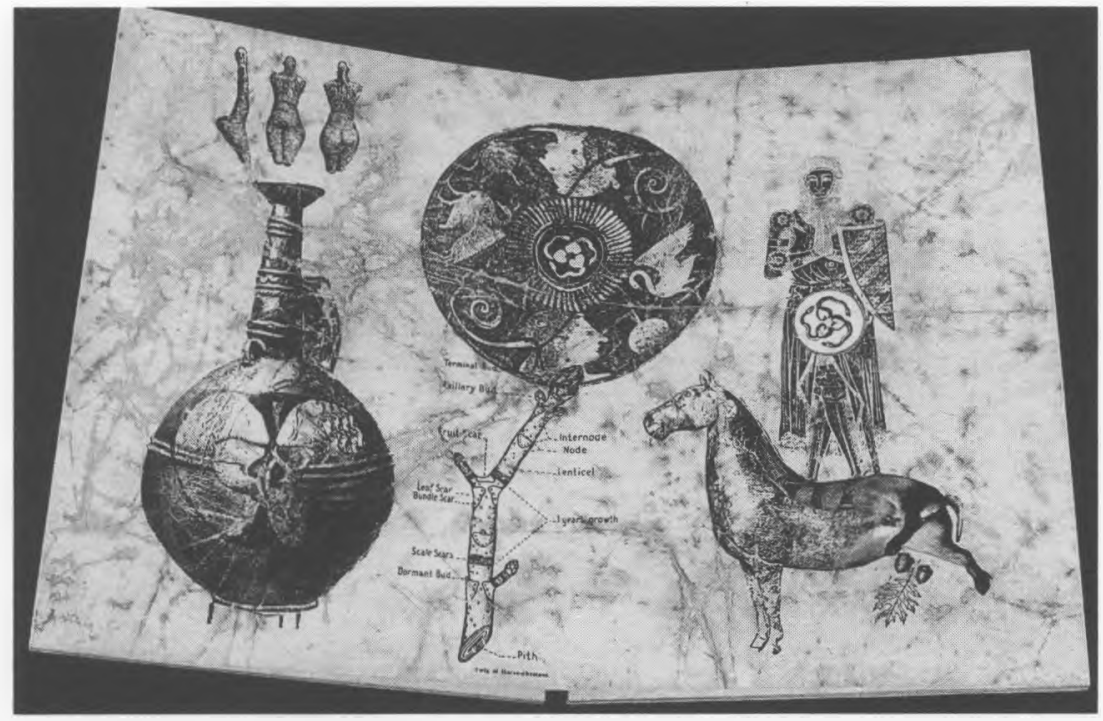

Scrutiny in the Great Round by Tennessee Rice Dixon.

of his concerns (language, consciousness, shamanism, the goddess, the psychedelic dimension, etc.) in a very condensed, nearly aphoristic form. In response to McKenna's text, Ely created two large paintings which were broken down to form the pages of the book. With the images and text in hand, poet, typographer and letterpress printer Philip Gallo at the Hermetic Press created a typographic form which serves to harmonize text and image. The wire-edge hinge binding was designed by Daniel E. Kelm and executed at the Wide Awake Garage. It is at once elegant and truly functional; the single page "signatures" open effortlessly and the book lies open flat with no strain.

Synesthesia, like several of the other Granary publications has a kind of alchemical character. Its meaning is not found precisely in determining what it is "about": rather it is an enactment of a visionary quality which asserts that the word and image, the book itself, are possible sites for transformation. Synesthesia is a collaboration in the largest sense of the word; 


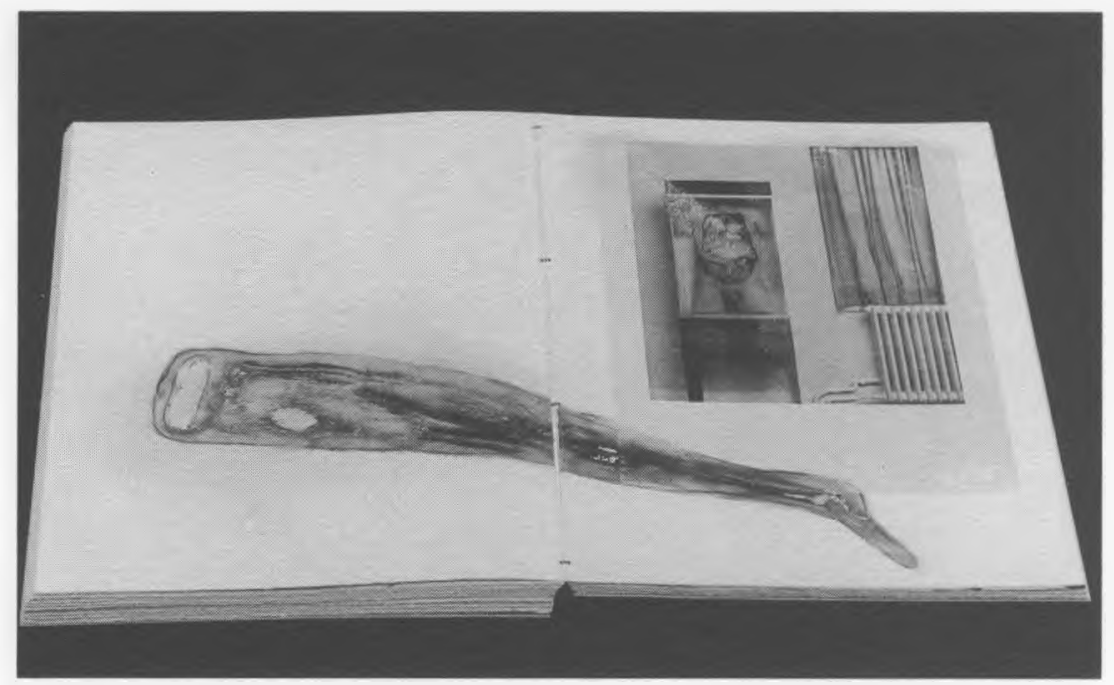

A Space for Breathing by Shelagh Keeley.

writer, artist, typographer, binder, and publisher each perform their role in an ongoing dialogue with each other.

Scrutiny in the Great Round, by Tennessee Rice Dixon, is an equally arcane and transformative work. Dixon is an artist who works primarily in drawing and collage. A series of her black and white photomontages, editioned on the copier, form the basis for this very personal investigation. Rooted in biology and informed by prophecy this book traces a lifeline in time: from before conception to after birth. A range of evolutionary characteristics, from sacred to profane, are here evoked through a visual narrative of intense investigation, potent with beauty. A host of images from seventeenth century alchemical engravings to twentieth century high school science book illustrations provide the background for Dixon's original collage, drawing and painting executed directly onto the pages of the book. The edition of seventeen (plus five artist and publisher copies) was again bound by Daniel Kelm and staff at the Wide Awake Garage.

A Space for Breathing is the second edition book by Shelagh Keeley published by Granary. Conceived as a companion volume to her 1991 publication Notes on the Body, Breathing 
juxtaposes the artist's original drawings in pencil, wax, pigment, gouache and ink with color photographic transfers. The transfers serve as that part of the edition which is mechanically reproduced; the drawings were made by the artist in each copy of the book. Shelagh Keeley has written: "In my installations I am concerned with recovery of space through gesture. There is an awareness of the body in my work process and my installations become psychological extensions of the body. Concerns in my work are: gestures of the body, gestures of the site, an architecture of emotion, the body and architecture." A Space for Breathing is an intense and beautiful synthesis of these themes and evokes a kind of epochal psycho-sexual narrative spoken within our bodies and within the architecture of the spaces our bodies inhabit. Once again, Daniel Kelm's wire-edge binding has been employed in this edition of twenty-two.

Taken as a group these books, along with the other Granary publications, shed light on a new area for investigation by artists which might be described as the unification of the space between drawing and books. The means of production would seem to preclude the possibility of "editioning" but through the repetition of image-making a kind of meditation evolves, the result of which is the creation of a variable edition where each book has the look and feel of a one-of-a-kind. The viewer or "reader" has direct experience of the artist's work, unmediated by more commercial or industrial forms of reproduction and is reminded of Ezra Pound's statement that "a book should be a ball of light you hold in your hands." 